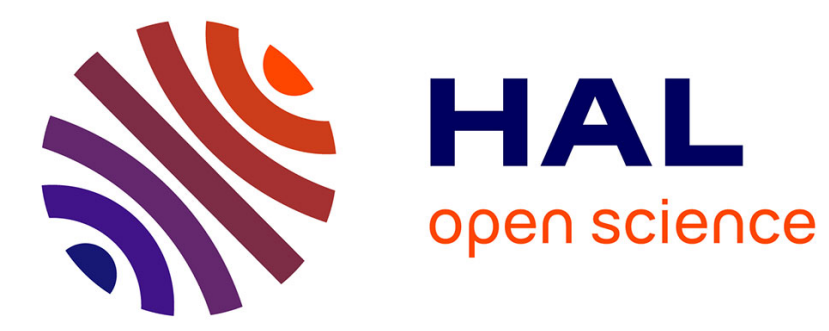

\title{
Cancer Stem-Like Cells in Glioblastoma
}

Mathilde Cheray, Gaëlle Bégaud, Elise Deluche, Alexandre Nivet, Serge

Battu, Fabrice Lalloué, Mireille Verdier, Barbara Bessette

\section{To cite this version:}

Mathilde Cheray, Gaëlle Bégaud, Elise Deluche, Alexandre Nivet, Serge Battu, et al.. Cancer StemLike Cells in Glioblastoma. Glioblastoma, 2017. hal-01829679

\section{HAL Id: hal-01829679 \\ https://hal.science/hal-01829679}

Submitted on 4 Jul 2018

HAL is a multi-disciplinary open access archive for the deposit and dissemination of scientific research documents, whether they are published or not. The documents may come from teaching and research institutions in France or abroad, or from public or private research centers.
L'archive ouverte pluridisciplinaire HAL, est destinée au dépôt et à la diffusion de documents scientifiques de niveau recherche, publiés ou non, émanant des établissements d'enseignement et de recherche français ou étrangers, des laboratoires publics ou privés. 


\title{
Cancer Stem-Like Cells in Glioblastoma
}

\author{
MATHILDE CHERAY ${ }^{1}$ • GAËLLE BÉGAUD ${ }^{2,3}$ • ELISE DELUCHE ${ }^{4} \bullet$ \\ ALEXANDRE NIVET ${ }^{5}$ • SERGE BATTU ${ }^{2,3}$ • FABRICE LALLOUÉ ${ }^{\bullet}$ \\ MIREILLE VERDIER ${ }^{* 2} \bullet$ BARBARA BESSETTE*2 $^{*}$
}

${ }^{1}$ Department of Oncology-Pathology, Cancer Centrum Karolinska, Stockholm, Sweden; ${ }^{2}$ EA3842 HCP, Faculty of Medicine, Limoges, France; ${ }^{3}$ Laboratory of Analytical Chemistry, Faculty of Pharmacy, Limoges, France; ${ }^{4}$ Oncology Department, University Hospital, Limoges, France; ${ }^{5}$ Radiotherapy Department, University Hospital, Limoges, France

Author for correspondence: Barbara Bessette, EA3842 HCP, Faculty of Medicine, Limoges, France. E-mail: barbara.bessette@unilim.fr Doi: http://dx.doi.org/10.15586/codon.glioblastoma.2017.ch4

\begin{abstract}
Glioblastoma is currently described as the worst brain tumor because of its aggressiveness and poor prognosis. Chemotherapy and irradiation are not curative, and the average survival for patients with glioblastoma is around 15 months. The cellular heterogeneity and infiltrative capability of glioblastoma make complete surgical resection almost impossible. Moreover, the presence of cancer stem-like cells in this tumor leads to therapeutic resistance and tumor recurrence after surgery. Numerous studies have explored the physiology of these cancer stem cells, and attempts have been made to develop devices aimed at isolating this rare population of cells. This chapter describes the complexity of cancer stem cells in glioblastoma. Their role in autophagy, gene regulation by epigenetic modifications, and the challenges in isolating these cells are addressed. This knowledge may pave the way for a better understanding of cancer stem cells in glioblastoma, and the potential development of new therapeutic strategies for this deadly disease.
\end{abstract}

Key words: Autophagy; Cancer stem cells; Epigenetic; Glioblastoma; SdFFF

\footnotetext{
* These authors contributed equally to the writing of this chapter.

In: Glioblastoma. Steven De Vleeschouwer (Editor), Codon Publications, Brisbane, Australia ISBN: 978-0-9944381-2-6; Doi: http://dx.doi.org/10.15586/codon.glioblastoma.2017
}

Copyright: The Authors.

Licence: This open access article is licenced under Creative Commons Attribution 4.0 International (CC BY 4.0). https://creativecommons.org/licenses/by-nc/4.0/ 


\section{Introduction}

Glioblastoma (GBM) is the most frequent and the most aggressive glial tumor of the central nervous system. Each year, about 240,000 cases of brain tumor are diagnosed worldwide, of which the majority are GBMs. Conventional therapeutic strategy is mainly surgery, in combination with temozolomide chemotherapy and radiation (corresponding to the Stupp protocol) (1). Novel drugs that are being developed include monoclonal antibodies against vascular endothelial growth factor (VEGF), inhibitors of tyrosine kinase receptors $(2,3)$, and Programmed death-ligand 1 (PD-L1) $(4,5)$. Despite recent advances, only a few patients with GBM are still alive 5 years after the initial diagnosis (3-10\%, depending on the applied protocol). The estimated survival time without progression of the disease hardly exceeds 18 months. Various reasons could explain such a poor outcome: late diagnosis, difficulty to clearly identify the tumor due to its histopathological heterogeneity, relapse of the tumor due to GBM cancer stem-like cells (CSCs), difficulties in identification and isolation of these cells, and paucity of knowledge about the physiology of CSCs. This chapter gives an overview of the complexity of GBM and the ongoing cell sorting methods.

\section{Evolution of Classifications and Diagnosis}

Reliable identification of tumors is a prerequisite for the development of efficient therapies. Because of the heterogeneity of the cells found in GBM, interobserver variability is not infrequent $(6,7)$, and this makes proper identification a difficult task. A tumor that has been initially identified as a GBM could turn out to be of a different type on subsequent analysis (7). These discrepancies justify the need for tools that will allow the unambiguous identification of GBM. GBM is the only solid tumor defined as higher grade tumor (grade IV) in the absence of any metastatic component. All other solid tumors can be classified (e.g., tumor-nodesmetastasis [TNM] classification of colon tumor), depending on their tissue infiltration, degree of cell differentiation, mitotic index, and metastatic invasion (8). Because of the complexity and the heterogeneity of GBM, the 2007 World Health Organization (WHO) classification of brain tumors was based only on the histological profile of the cells, combined with their mitotic index and molecular criteria (9). Different kinds of GBM were listed in this classification: pure astrocytoma, oligoastrocytoma, and neuro-astrocytoma. The $2016 \mathrm{WHO}$ classification developed a new approach (10) that primarily relies on the genetic profile of the tumor. The most notable changes are in the isocitrate dehydrogenase (IDH) status (mutated vs. wild type) and the detection of 1p19q co-deletion. Importantly, if the histological phenotype and the genotype are nonconcordant, then the genotype will take over and will be used to determine the diagnosis and subsequent therapeutic decision-making. This guideline, associated with the mitotic index and the histological nature of the cells, helps to orientate the therapeutic scheme. In this way, the current WHO classification not only allows to determine the nature of the tumor but also enables to make a choice for therapeutic management. 


\section{Cancer Stem Cells in Glioblastoma}

\section{CANCER STEM CELL IDENTIFICATION}

CSCs were initially reported by Singh et al., who described a subpopulation of cells positive for CD133 that were able to initiate tumors in vivo (11). Hence, they were termed "tumor initiating cells" (11). Solid tumors such as GBMs are characterized by a high degree of heterogeneity, which has been explained by two different theories. According to the first theory, the stochastic model, tumor cells share the same genetic mutations (homogeneous), and heterogeneity is the result of intrinsic as well as extrinsic factors. According to the second theory, the hierarchy model, cells are intrinsically different in terms of differentiation stage and only a small subset, the CSCs, can initiate tumor growth and progression (12). This subpopulation is increasingly referred to as the cause of tumor onset and recurrence as well as therapeutic resistance. The difficulty encountered in studying CSCs is largely the result of challenges in precisely identifying them (13). Although CD133 is classically associated with this cell subset, it is also expressed in normal neural stem cells; thus, the relevance of this biomarker is still a matter of debate when it comes to GBM stem cells. Indeed, it has been shown that CD133 ${ }^{\text {neg }}$ cells are also capable of inducing tumors when implanted in rat brains (14). Consequently, it is now recognized that additional markers are needed to identify this subpopulation. Among these markers, $\mathrm{CD} 44$ and $\mathrm{ABC}$ transporters are probably the most reliable. Recently, our team contributed to identify a new GBM stem-like cell marker, the KLRC3 gene coding for NKG2E, a protein expressed in natural killer cells (15). We showed that the silencing of KLRC3 decreased self-renewal, invasion, and proliferation capacities, along with radioresistance and tumorigenicity of the U87-MG GBM cell line. Transcription factors such as sox2, oct4, Bmil, and nanog are also known to contribute to the stemness properties of CSCs (16). Researchers currently working on this peculiar cell subpopulation consider that seeking more than a single marker is mandatory to identify and/or enrich this population. These potential molecular markers, combined with functional properties, such as selfrenewal and cancer-initiation capacities, will enable the identification and enrichment of this subpopulation of cells.

\section{AUTOPHAGY}

Similar to many solid tumors, GBM development leads to the formation of hypoxic areas. Uncontrolled proliferation of tumors, especially in the high cellular density pseudo-palisading region, leads to a decrease in $\mathrm{O}_{2}$ tension. In response to this stress, cancer cells stabilize the hypoxia-inducible factor 1 (HIF-1), which in turn induces overexpression of VEGF (17). The binding of this growth factor to its receptor on endothelial cells promotes neoangiogenesis. This vascularization is characterized by abnormal, dysfunctional, and/or occluded vessels, which are unable to sustain normoxia, hence the formation of hypoxic regions. Although a hypoxic microenvironment could induce cell death in normal conditions, it is also well known to maintain CSCs, especially in GBM (18). While actively proliferating cells are more likely to be found close to the vessels, stem-like cells lie in the central parts of the tumor, the core region, which 
contributes to a CSC niche. The core region is more likely to be radioresistant and chemoresitant, and usually necrotic. These different distributions of cells illustrate the GBM heterogeneity. CSC population density and aggressiveness are inversely related to oxygen tension (19).

In the context of vasculature and oxygen supply deficiency, several studies, including ours, demonstrated that autophagy is induced as a cytoprotective mechanism $(20,21)$. This catabolic process, which is complementary to the ubiquitin-proteasome system, leads altered organelles and proteins to lysosomes where they are degraded. Besides basal physiological level, autophagy is upregulated when cells are subjected to various stresses such as nutrient starvation, oxygen deprivation, or therapy (22). In GBM, hypoxia-induced autophagy promotes cell survival and aggressiveness. This could be explained in part by the pro-survival effects of autophagy in response to antiangiogenic therapy, leading to hypoxia (23). Furthermore, it has been shown that antiangiogenic agents targeting VEGF or its receptor induce expansion of CSCs in tumors implanted in animals, supporting the link between hypoxia-induced autophagy and stemness (24). Another major function of autophagy is to supply metabolic precursors, such as amino acids and/or fatty acids, via the catabolic process, which contributes to energy supply and cellular homeostasis. When microenvironment is unfriendly, autophagy is likely to be enhanced in CSCs to allow cell viability and quiescence (25). Such a response has also been demonstrated during temozolomide chemotherapy or radiotherapy $(26,27)$. Both treatments are known to favor conservation of the CSC subset, which is responsible for therapy escape and tumor recurrence. Consequently, the use of autophagy inhibitors, such as chloroquine or its analog hydroxychloroquine, combined with classical therapy (i.e., temozolomide), appears to enhance the cytotoxicity against CSCs (28). Prospective studies are needed to better delineate the exact application and efficiency of this combination treatment, where autophagy inhibition could represent an adjuvant cancer therapy.

\section{EPIGENETIC REGULATION}

Cells constantly change their state of equilibrium in response to internal and external stimuli. These changes in cell identity are driven by highly coordinated modulation of gene expression, which is achieved largely by changes in the structure and composition of the chromatin, driven by epigenetic modulators. Epigenetic modifications such as histone modification and DNA methylation are crucial for normal development but can also be involved in cancer initiation and progression. Recent discoveries in cellular and genomic reprogramming have highlighted the importance of chromatin modifications in the regulation of CSC in GBM.

\section{HISTONE MODIFICATIONS}

Histones can be subjected to posttranslational modifications which alter their interaction with DNA and nuclear proteins. Modifications of the histone tails include methylation, acetylation, and phosphorylation, among others. Chromatin opening through the methylation of $\mathrm{H} 3 \mathrm{~K} 4$ (Lysine 4 of Histone 3) allows transcription to be performed, whereas chromatin closing through H3K9 and 
H3K27 methylations (Lysine 9 and Lysine 27 of Histone 3) constitutes the two main repressive mechanisms in mammalian cells. In a study of 230 gliomas, the global expression of several histone modification markers was assessed using immunocytochemistry. Based on WHO grade, histology, and histone modifications, H3K9ac (acetylation of Lysine 9 of Histone 3), H3K4me2 (dimethylation of Lysine 4 of Histone 3), H3K18ac (acetylation of Lysine 18 of Histone 3), and H4K20me3 (trimethylation of Lysine 20 of Histone 4), 10 distinct prognostic groups were generated, suggesting that aberrant histone modifications can have a role in GBM (29).

In the case of CSCs, it has been demonstrated that CD133 expression is regulated by H3K9me2. CD133-positive cells, which are usually considered as CSCs, were found to be H3K9me2 negative, whereas most cancer cells were found to be H3K9me2 positive. In their study, Tao et al. demonstrated that the G9adependent H3K9me2 repression of CD133 was one of the crucial switches for the self-renewal of CSCs, similar to the embryonic stem cells (30). Transcriptional repression by histone methylation is facilitated by polycomb genes like EZH2 and Bmil and had been linked to differentiation and self-renewal abilities of CSCs. EZH2 silencing of the BMP pathway in CSCs inhibits their ability to differentiate. Moreover, inhibition of EZH2 or forced expression of methylatedpromoter-repressed BMP pathway restores normal differentiation capacity of CSCs. This reduces proliferation and induces terminal differentiation of CSCs, causing loss of self-renewal and a decrease in tumorigenicity of CSCs $(31,32)$. Bmil, a key component of the polycomb repressive complex 1 ( $\mathrm{PRCl}$ ), is upregulated in GBM and significantly enriched in the CSC population, but it is not expressed in normal astrocytes. Moreover, its suppression in human CSCs inhibits their growth in vitro and in vivo (33). Finally, the expression inhibition of Bmil by knockdown in a glioma mouse model suppresses the formation of malignant tumors (34).

\section{DNA METHYLATION}

DNA methylation, catalyzed by DNA methyltransferases (DNMTs), is a major epigenetic modification that modulates gene expression. DNA methylation patterns are heritable and reversible, conserved during cell division, and involved in cell reprogramming processes. DNA methylation directly represses gene expression via the inhibition of transcription factor recruitment (35). Transcription inhibition could also be indirect through the recruitment of methyl-CpG-binding proteins and their associated repressive chromatin remodeling activities (36). DNA methylation deregulation is found in cancer where hypermethylation of specific tumor suppressor genes (TSGs) leads to the inhibition of their expression. It is known that aberrant DNA methylation is linked to the initiation and the progression of cancer. Global DNA hypomethylation promotes chromosomal instability, reactivation of transposable elements, and loss of imprinting. Local hypomethylation induces oncogene activation, while hypermethylation induces the silencing of TSGs (37). Aberrant DNA methylation patterns have been detected in GBM. A well-studied example is the silencing of the DNA repair enzyme MGMT ( $\mathrm{O}^{6}$-methylguanine-DNA methyltransferase) following hypermethylation of the MGMT CpG island. Methylation of the MGMT promoter results in defects in DNA repair and is associated with a better response to 
treatment with alkylating agents (38). MGMT methylation status is now used in the clinical management of GBM patients as a biomarker for predicting drug responsiveness.

Epigenetic changes like DNA methylation can be involved in the adaptation of CSCs to the environment in such a way that they reinforce the malignant state of the tumor. For example, it has been shown that the resetting of DNA methylation by induction of pluripotent stem cell reprogramming, followed by lineage differentiation, suppresses the malignant properties of GBM (39). Moreover, in CSCs, the cell-surface marker CD133, defined as a CSC-specific marker, is found methylated. In their study, Gopisetty et al. showed that Spl and Myc regulate CD133 transcription in CSCs and that promoter methylation and methyl-DNAbinding proteins cause repression of CD133 by excluding transcription-factor binding (40). Expression of the transcriptional coactivator with PDZ-binding motif (TAZ) has been linked to GBM subtype. It has been shown that its silencing in mesenchymal CSCs suppress the mesenchymal gene expression signature, while expressing TAZ in proneural CSCs, leading to increased expression of mesenchymal signature genes (41).

More recently, taking advantage of the genome-wide analysis technology, it has been shown that specific DNA methylation patterns were associated with CSCs. Concurrent promoter hypermethylation and gene body hypomethylation were observed in a subset of genes, including MGMT, AJAP1, and PTPRN2. These unique DNA methylation signatures were also found in primary GBM-derived xenograft tumors, indicating that they are not tissue culture-related epigenetic changes. Integration of GSC-specific epigenetic signatures with gene expression analysis further identified candidate TSGs that are frequently downregulated in GBMs, such as SPINT2, NEFM, and PENK (42).

\section{Isolation of Cancer Stem Cells in Glioblastoma}

Because of their key roles in tumorigenesis, metastasis, and therapeutic relapses, CSCs appear as major biological and therapeutic targets, in particular for GBM (43-46). This cellular status fully justifies the discovery, development, and validation of methods allowing purification and characterization of CSCs (43-46). However, the heterogeneity of the tumor cell population, the rarity of CSCs within the tumor mass (1-5\%, depending on the type of cancer (43)), the difficulty in accurately defining their properties, and the criteria on which the sorting and characterization methods are based $(44,45,47,48)$ continue to pose major challenges.

\section{FUNCTIONAL TESTS}

CSCs are known to display different properties which give them the ability to relapse, and be more resistant to chemotherapy $(49,50)$ or radiation therapy (51). These properties are currently being investigated in order to better characterize CSCs. The self-renewal of CSCs (which is one of the properties defining CSCs) can be determined with two different tests: the colony forming 
unit approach and the limiting dilution assay. Both tests are based on the ability of a single CSC to proliferate and create a new neurosphere in vitro (49). CSCs share common properties with normal stem cells such as their ability to differentiate into specific cell lineage. For GBM, the CSCs should be able to differentiate into neurons, astrocytes, and oligodendrocytes. Moreover, the most important feature of CSCs is their ability to resist treatment $(50,51)$. In GBM, this property leads to tumor relapse and unfortunately to patient death. The most conventional approach includes the evaluation of the apoptotic impact of temozolomide and/or radiation on CSCs. A strong resistance to these treatments is a characteristic of CSC (52). Finally, the capability of CSC to form a tumor has to be addressed by xenograft or orthotopic cell engraftment (51).

\section{CLASSICAL CELL SORTING METHODS}

The classical cell sorting methods are based on the recognition of specific extracellular or intracellular antigens using fluorescent (FACS) or magnetic (MACS) probes. Other methods such as affinity chromatography, panning, and aptamers also use the immunological recognition principle $(44,47,48)$. In GBM, some of the most useful markers are SOX2, OCT4, NANOG, CD133, and ABCG2 $(44,45,53)$. However, no single marker can be considered a gold standard, and, therefore, a series of markers is mandatory to validate the stemness status. Aldehyde dehydrogenase (ALDH) activity can be used in addition to the above staining. High ALDH expression has been reported in precursor cells of GBM. Another way to separate CSCs from GBM is the detection of the side population using Hoechst staining. However, this labeling could lead to functional modifications of the cell such as induction of cell differentiation and therefore difficulties for in vitro studies (culture, graft, etc.) $(44,47)$.

\section{SEDIMENTATION FIELD-FLOW FRACTIONATION CELL SORTING}

Field-flow fractionation (FFF) techniques were developed by J.C. Giddings in the late 1960s (54). FFF methods are considered as gentle methods as cells are sorted by applying low-intensity forces: (i) one corresponding to an external multigravitational field due to the channel rotation and (ii) the other corresponding to hydrodynamic lift-forces due to the flowing of the cells in the mobile phase (Figure 1). The balance of these two forces leads to the focusing of identical subpopulations (with respect to size, density, shape, and rigidity) into thin layers, which are eluted from the flow stream passing through their gravitational center (hyperlayer elution mode) (55). Sedimentation field-flow fractionation (SdFFF) is a gentle (low flow rate and low external field to limit shear forces exerted on cells) and noninvasive method, which takes into account, without any labeling, a complex matrix of cell properties such as the size, the cell-cycle position (related to the density), or the rigidity of the cytoskeleton, which are the major properties of stem cells. Usually, the largest and less dense cells (the most differentiated) are eluted first, while the smallest and the most dense cells (low nucleo-cytoplasmic ratio corresponding to stems cells) are eluted last. This elution order also depends on the ploidy or the 


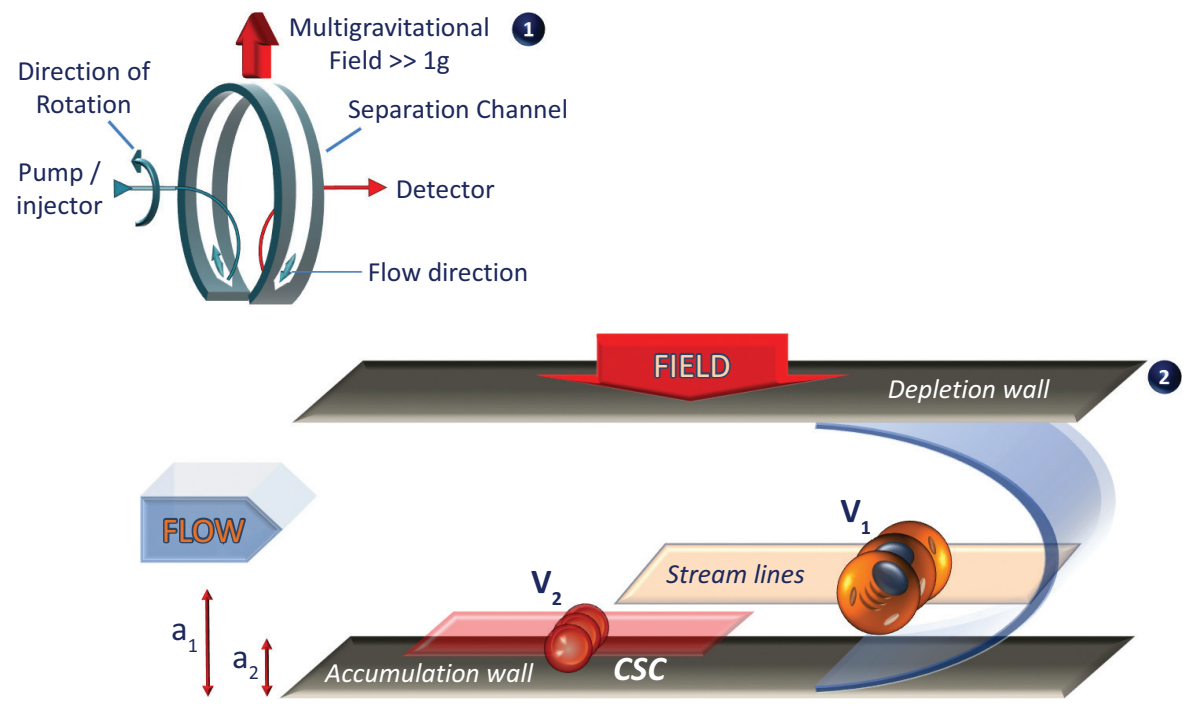

Figure 1 (1) Schematic representation of an SdFFF separation channel and its implementation in the chromatographic chain. (2) Schematic representation of hyperlayer elution mode and cell elution order depending on the size. a: distance from the center of gravity of the cell to the accumulation wall. $\mathrm{V}$ : velocity of cells.

position in the cell cycle; the cells eluted in the last fraction are usually in the G0/G1 phase $(56,57)$.

Our first work on CSC isolation began with human neuroblastoma cell lines (SKNSH-SY5Y, IMR-32) and was then followed by the U87-MG human GBM cell line analysis (58-60). We demonstrated that cells eluted in the ultimate part of the fractogram (Figure 2) overexpressed vimentin and CD133, presented the ability to form neurospheres in defined culture medium, and were resistant to Fas-induced apoptosis. To increase the purity and the diversity of subpopulations with different degrees of differentiation, we developed an analytical SdFFF protocol using different external fields. The following four cell culture conditions were tested: normal (+ FBS), defined ( - FBS), normoxia, and hypoxia $\left(\mathrm{O}_{2}<0.1 \%\right)$. Defined culture medium and hypoxia mimicked the conditions found in the tumor niche and yielded an enriched CSC population. The use of two different fields in SdFFF allowed the separation of differentiated cells at $25 \mathrm{~g}$, while a lower field of $15 \mathrm{~g}$ favored the isolation of CSCs. Eight different subpopulations were identified based on the expression of CD133, NCAM, nestin, Oct4, A2B5, cell-cycle position, ALDH activity, and clonogenicity (Figure 2). As described in Figure 2, differentiated cells are eluted in the fraction Fl of cells cultured in normal culture medium under normoxia,at $25 \mathrm{~g}$. The most undifferentiated cells were obtained by collecting fraction F3 at $15 \mathrm{~g}$ from cells cultured in defined medium under hypoxic conditions. These populations should be further used to identify CSC properties or to test their sensitivity to therapy. 


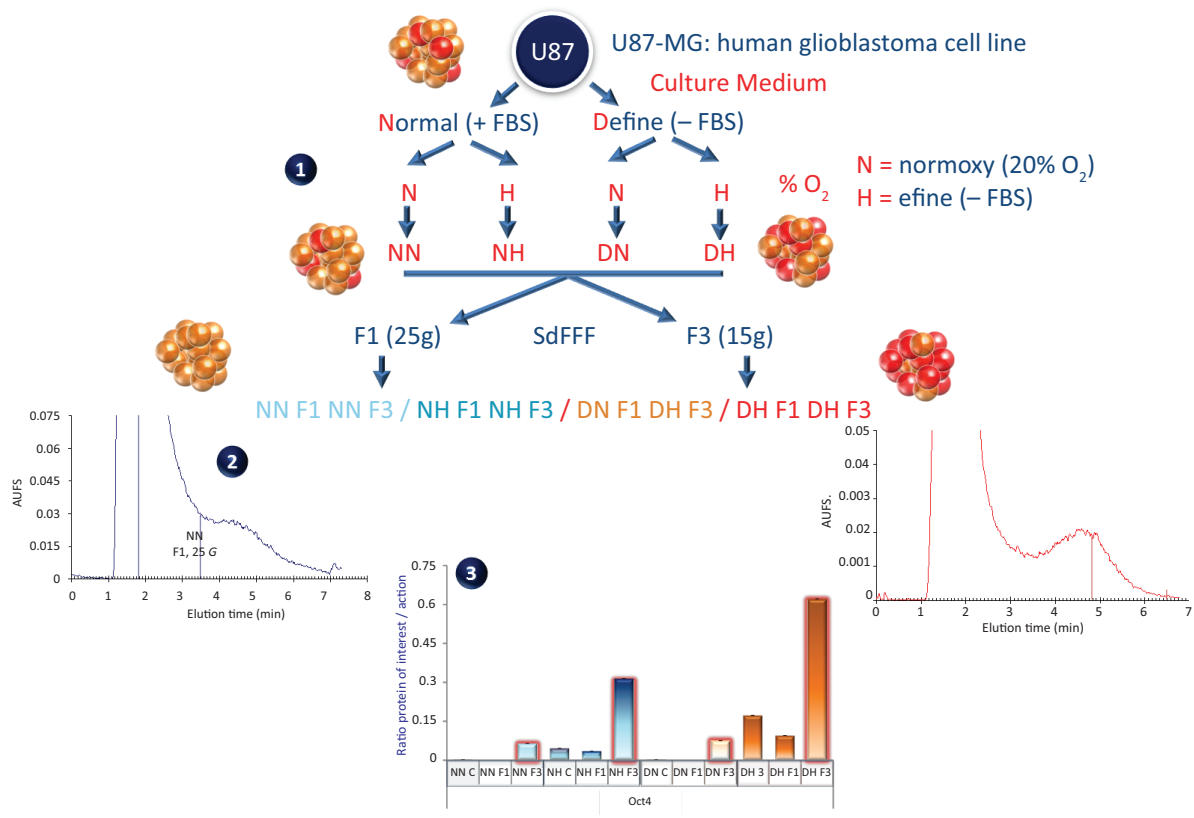

Figure 2 Representation of the global method used to enrich CSCs from human glioblastoma cell line. Four conditions are established with different media and oxygen tensions, namely, NN, $\mathrm{NH}, \mathrm{DN}$, and $\mathrm{DH}$, in order to obtain a matrix of CSCs enrichment (1). CSC level is increased by the use of SdFFF cell sorting method (2: representative fractograms). Oct4 stem cell marker expression (3) in subpopulations obtained after SdFFF sorting (F1/F3), compared to crude (C) populations. Concerning fractograms (2), the optimal elution conditions were: injection of $2 \times 10^{5}$ U87-MG cells; flow rate: $0.80 \mathrm{~mL} / \mathrm{min}$; mobile phase: sterile $\mathrm{PBS}, \mathrm{pH}=7.4$; and external multi-gravitational field strength: 15 or $25.00 \pm 0.02 \mathrm{~g}$ (312 or $412 \pm 0.2 \mathrm{rpm}$ ). These optimal elution conditions allowed cell separation under the biocompatible hyperlayer elution mode. Time-dependent collected fractions F1 and F3 corresponded to differentiated and cancer stem cells, respectively.

\section{Conclusion}

Despite current advances in the study of GBM and the physiology of GBM CSCs, it remains impossible to cure GBM. To develop a better therapy, one of the steps would be the development of new methods such as SdFFF that allow the isolation of CSCs without causing any cellular modification. The ability of tumor cells to adapt to their environment is of great interest and mechanisms by which tumor cells communicate with their microenvironment are increasingly being investigated. Studies concerning exosomes (vesicles excreted from cells) and their role in cancer progression underline new point of views on tumors including GBM $(61,62)$. Numerous studies are also being performed on the epigenetic profile of tumor cells, which could be involved in cell reprogramming and adaptation to their environment. Together, these approaches could enable a better understanding of the role of CSCs in GBM initiation and progression, and help develop novel therapeutics in the days to come. 
Acknowledgment: This work was supported by grants from Conseil Régional du Limousin, Ligue Nationale Contre le Cancer (comités de la Creuse, Corrèze et de la Haute Vienne), and CORC (Comité d'Organisation de la Recherche sur le Cancer du Limousin). The authors thank Dr. Michel Guilloton for his help in editing the manuscript.

Conflict of interest: The authors declare no potential conflicts of interest with respect to research, authorship, and/or publication of this manuscript.

Copyright and permission statement: To the best of our knowledge, the materials included in this chapter do not violate copyright laws. All original sources have been appropriately acknowledged and/or referenced. Where relevant, appropriate permissions have been obtained from the original copyright holder(s).

\section{References}

1. Stupp R, Mason WP, van den Bent MJ, Weller M, Fisher B, Taphoorn MJ, et al. Radiotherapy plus concomitant and adjuvant temozolomide for glioblastoma. N Engl J Med. 2005 Mar 10;352(10):987-96. http://dx.doi.org/10.1056/NEJMoa043330

2. Erdem-Eraslan L, van den Bent MJ, Hoogstrate Y, Naz-Khan H, Stubbs A, van der Spek P, et al. Identification of patients with recurrent glioblastoma who may benefit from combined bevacizumab and CCNU therapy: A report from the BELOB trial. Cancer Res. 2016 Feb 01;76(3):525-34. http:// dx.doi.org/10.1158/0008-5472.CAN-15-0776

3. Schafer N, Gielen GH, Kebir S, Wieland A, Till A, Mack F, et al. Phase I trial of dovitinib (TKI258) in recurrent glioblastoma. J Cancer Res Clin Oncol. 2016;142(7):1581-9. http://dx.doi.org/10.1007/ s00432-016-2161-0

4. Tang X, Li Q, Zhu Y, Zheng D, Dai J, Ni W, et al. The advantages of PDl activating chimeric receptor (PDl-ACR) engineered lymphocytes for PDLl(+) cancer therapy. Am J Transl Res. 2015;7(3):460-73.

5. Heiland DH, Haaker G, Delev D, Mercas B, Masalha W, Heynckes S, et al. Comprehensive analysis of PD-Ll expression in glioblastoma multiforme. Oncotarget. 2017 Jun 27;8(26):42214-25. http:// dx.doi.org/10.18632/oncotarget.15031

6. Scott CB, Nelson JS, Farnan NC, Curran WJ, Jr., Murray KJ, Fischbach AJ, et al. Central pathology review in clinical trials for patients with malignant glioma. A report of Radiation Therapy Oncology Group 83-02. Cancer. 1995 Jul 15;76(2):307-13. http://dx.doi.org/10.1002/1097-0142 (19950715)76:2\%3C307::AID-CNCR2820760222\%3E3.0.CO;2-L

7. Kim BY, Jiang W, Beiko J, Prabhu SS, DeMonte F, Gilbert MR, et al. Diagnostic discrepancies in malignant astrocytoma due to limited small pathological tumor sample can be overcome by IDHl testing. J Neuro Oncol. 2014 Jun;118(2):405-12. http://dx.doi.org/10.1007/s11060-014-1451-0

8. Lo DS, Pollett A, Siu LL, Gallinger S, Burkes RL. Prognostic significance of mesenteric tumor nodules in patients with stage III colorectal cancer. Cancer. 2008 Jan 01;112(1):50-4. http://dx.doi.org /10.1002/cncr.23136

9. Louis DN, Ohgaki H, Wiestler OD, Cavenee WK, Burger PC, Jouvet A, et al. The 2007 WHO classification of tumours of the central nervous system. Acta Neuropathol. 2007 Aug;114(2):97-109. http:// dx.doi.org/10.1007/s00401-007-0243-4

10. Louis DN, Perry A, Reifenberger G, von Deimling A, Figarella-Branger D, Cavenee WK, et al. The 2016 World Health Organization classification of tumors of the central nervous system: A summary. Acta Neuropathol. 2016 Jun;131(6):803-20. http://dx.doi.org/10.1007/s00401-016-1545-1

11. Singh SK, Hawkins C, Clarke ID, Squire JA, Bayani J, Hide T, et al. Identification of human brain tumour initiating cells. Nature. 2004 Nov 18;432(7015):396-401. http://dx.doi.org/10.1038 /nature03128 
12. Catalano V, Gaggianesi M, Spina V, Iovino F, Dieli F, Stassi G, et al. Colorectal cancer stem cells and cell death. Cancers. 2011 Apr 11;3(2):1929-46. http://dx.doi.org/10.3390/cancers3021929

13. Abbaszadegan MR, Bagheri V, Razavi MS, Momtazi AA, Sahebkar A, Gholamin M. Isolation, identification, and characterization of cancer stem cells: A review. J Cell Physiol. 2017 Aug;232(8): 2008-18.

14. Wang J, Sakariassen PO, Tsinkalovsky O, Immervoll H, Boe SO, Svendsen A, et al. CD133 negative glioma cells form tumors in nude rats and give rise to CD133 positive cells. Int J Cancer. 2008 Feb 15;122(4):761-8. http://dx.doi.org/10.1002/ijc.23130

15. Cheray M, Bessette B, Lacroix A, Melin C, Jawhari S, Pinet S, et al. KLRC3, a Natural Killer receptor gene, is a key factor involved in glioblastoma tumourigenesis and aggressiveness. J Cell Mol Med. 2017 Feb;21(2):244-53. http://dx.doi.org/10.1111/jcmm. 12960

16. Yi Y, Hsieh IY, Huang X, Li J, Zhao W. Glioblastoma stem-like cells: Characteristics, microenvironment, and therapy. Front Pharmacol. 2016;7:477. http://dx.doi.org/10.3389/fphar.2016.00477

17. Kaur B, Khwaja FW, Severson EA, Matheny SL, Brat DJ, Van Meir EG. Hypoxia and the hypoxiainducible-factor pathway in glioma growth and angiogenesis. Neuro Oncol. 2005 Apr;7(2):134-53. http://dx.doi.org/10.1215/S1152851704001115

18. Heddleston JM, Li Z, McLendon RE, Hjelmeland AB, Rich JN. The hypoxic microenvironment maintains glioblastoma stem cells and promotes reprogramming towards a cancer stem cell phenotype. Cell Cycle. 2009 Oct 15;8(20):3274-84. http://dx.doi.org/10.4161/cc.8.20.9701

19. Persano L, Rampazzo E, Basso G, Viola G. Glioblastoma cancer stem cells: Role of the microenvironment and therapeutic targeting. Biochem Pharmacol. 2013 Mar 01;85(5):612-22. http://dx.doi. org/10.1016/j.bcp.2012.10.001

20. Hu YL, DeLay M, Jahangiri A, Molinaro AM, Rose SD, Carbonell WS, et al. Hypoxia-induced autophagy promotes tumor cell survival and adaptation to antiangiogenic treatment in glioblastoma. Cancer Res. 2012 Apr 01;72(7):1773-83. http://dx.doi.org/10.1158/0008-5472.CAN-11-3831

21. Jawhari S, Bessette B, Hombourger S, Durand K, Lacroix A, Labrousse F, et al. Autophagy and TrkC/NT-3 signaling joined forces boost the hypoxic glioblastoma cell survival. Carcinogenesis. 2017;38(6):592-603. http://dx.doi.org/10.1093/carcin/bgx029

22. Feng Y, Yao Z, Klionsky DJ. How to control self-digestion: Transcriptional, post-transcriptional, and post-translational regulation of autophagy. Trends Cell Biol. 2015 Jun;25(6):354-63. http://dx.doi. org/10.1016/j.tcb.2015.02.002

23. Jawhari S, Ratinaud MH, Verdier M. Glioblastoma, hypoxia and autophagy: A survival-prone "menagea-trois." Cell Death Dis. 2016 Oct 27;7(10):e2434. http://dx.doi.org/10.1038/cddis.2016.318

24. Piao Y, Liang J, Holmes L, Zurita AJ, Henry V, Heymach JV, et al. Glioblastoma resistance to anti-VEGF therapy is associated with myeloid cell infiltration, stem cell accumulation, and a mesenchymal phenotype. Neuro Oncol. 2012 Nov;14(11):1379-92. http://dx.doi.org/10.1093/neuonc /nos 158

25. Guan JL, Simon AK, Prescott M, Menendez JA, Liu F, Wang F, et al. Autophagy in stem cells. Autophagy. 2013 Jun 01;9(6):830-49. http://dx.doi.org/10.4161/auto.24132

26. Ojha R, Bhattacharyya S, Singh SK. Autophagy in cancer stem cells: A potential link between chemoresistance, recurrence, and metastasis. BioRes Open Access. 2015;4(1):97-108. http://dx.doi.org/10.1089/ biores.2014.0035

27. Koukourakis MI, Mitrakas AG, Giatromanolaki A. Therapeutic interactions of autophagy with radiation and temozolomide in glioblastoma: Evidence and issues to resolve. Br J Cancer. 2016 Mar 01;114(5):485-96. http://dx.doi.org/10.1038/bjc.2016.19

28. Rangwala R, Leone R, Chang YC, Fecher LA, Schuchter LM, Kramer A, et al. Phase I trial of hydroxychloroquine with dose-intense temozolomide in patients with advanced solid tumors and melanoma. Autophagy. 2014 Aug;10(8):1369-79. http://dx.doi.org/10.4161/auto.29118

29. Liu BL, Cheng JX, Zhang X, Wang R, Zhang W, Lin H, et al. Global histone modification patterns as prognostic markers to classify glioma patients. Cancer Epidemiol Biomarkers Prev. 2010 Nov;19(11):2888-96. http://dx.doi.org/10.1158/1055-9965.EPI-10-0454

30. Tao H, Li H, Su Y, Feng D, Wang X, Zhang C, et al. Histone methyltransferase G9a and H3K9 dimethylation inhibit the self-renewal of glioma cancer stem cells. Mol Cell Biochem. 2014 Sep; 394(1-2):23-30. http://dx.doi.org/10.1007/s11010-014-2077-4 
31. Lee J, Son MJ, Woolard K, Donin NM, Li A, Cheng CH, et al. Epigenetic-mediated dysfunction of the bone morphogenetic protein pathway inhibits differentiation of glioblastoma-initiating cells. Cancer Cell. 2008 Jan;13(1):69-80. http://dx.doi.org/10.1016/j.ccr.2007.12.005

32. Suva ML, Riggi N, Janiszewska M, Radovanovic I, Provero P, Stehle JC, et al. EZH2 is essential for glioblastoma cancer stem cell maintenance. Cancer Res. 2009 Dec 15;69(24):9211-18. http://dx.doi. org/10.1158/0008-5472.CAN-09-1622

33. Abdouh M, Facchino S, Chatoo W, Balasingam V, Ferreira J, Bernier G. BMIl sustains human glioblastoma multiforme stem cell renewal. J Neurosci. 2009 Jul 15;29(28):8884-96. http://dx.doi. org/10.1523/JNEUROSCI.0968-09.2009

34. Bruggeman SW, Hulsman D, Tanger E, Buckle T, Blom M, Zevenhoven J, et al. Bmil controls tumor development in an Ink4a/Arf-independent manner in a mouse model for glioma. Cancer Cell. 2007 Oct;12(4):328-41. http://dx.doi.org/10.1016/j.ccr.2007.08.032

35. Prendergast GC, Ziff EB. Methylation-sensitive sequence-specific DNA binding by the c-Myc basic region. Science. 1991 Jan 11;251(4990):186-9. http://dx.doi.org/10.1126/science.1987636

36. Robertson KD. DNA methylation and chromatin-Unraveling the tangled web. Oncogene. 2002 Aug 12;21(35):5361-79. http://dx.doi.org/10.1038/sj.onc.1205609

37. Esteller M. Epigenetics in cancer. N Engl J Med. 2008 Mar 13;358(11):1148-59. http://dx.doi. org/10.1056/NEJMra072067

38. Paz MF, Yaya-Tur R, Rojas-Marcos I, Reynes G, Pollan M, Aguirre-Cruz L, et al. CpG island hypermethylation of the DNA repair enzyme methyltransferase predicts response to temozolomide in primary gliomas. Clin Cancer Res. 2004 Aug 01;10(15):4933-8.

39. Stricker SH, Feber A, Engstrom PG, Caren H, Kurian KM, Takashima Y, et al. Widespread resetting of DNA methylation in glioblastoma-initiating cells suppresses malignant cellular behavior in a lineage-dependent manner. Genes Dev. 2013 Mar 15;27(6):654-69. http://dx.doi.org/10.1101/ gad.212662.112

40. Gopisetty G, Xu J, Sampath D, Colman H, Puduvalli VK. Epigenetic regulation of CD133/PROMI expression in glioma stem cells by Spl/myc and promoter methylation. Oncogene. 2013 Jun 27;32(26):3119-29. http://dx.doi.org/10.1038/onc.2012.331

41. Bhat KP, Salazar KL, Balasubramaniyan V, Wani K, Heathcock L, Hollingsworth F, et al. The transcriptional coactivator TAZ regulates mesenchymal differentiation in malignant glioma. Genes Dev. 2011 Dec 15;25(24):2594-609. http://dx.doi.org/10.1101/gad.176800.111

42. Lee EJ, Rath P, Liu J, Ryu D, Pei L, Noonepalle SK, et al. Identification of Global DNA Methylation signatures in glioblastoma-derived cancer stem cells. J Genet Genomics. 2015 Jul 20;42(7):355-71.

43. Boman BM, Wicha MS. Cancer stem cells: A step toward the cure. J Clin Oncol. 2008 Jun 10;26(17):2795-9. http://dx.doi.org/10.1200/JCO.2008.17.7436

44. Islam F, Gopalan V, Smith RA, Lam AKY. Translational potential of cancer stem cells: A review of the detection of cancer stem cells and their roles in cancer recurrence and cancer treatment. Exp Cell Res. 2015 Jul 1;335(1):135-47. http://dx.doi.org/10.1016/j.yexcr.2015.04.018

45. Lathia JD, Mack SC, Mulkearns-Hubert EE, Valentim CLL, Rich JN. Cancer stem cells in glioblastoma. Genes Dev. 2015 Jun;29(12):1203-17. http://dx.doi.org/10.1101/gad.261982.115

46. Gilbert CA, Ross AH. Cancer stem cells: Cell culture, markers, and targets for new therapies. J Cell Biochem. 2009 Dec 1;108(5):1031-8. http://dx.doi.org/10.1002/jcb.22350

47. Diogo MM, da Silva CL, Cabral JMS. Separation technologies for stem cell bioprocessing. Biotechnol Bioeng. 2012 Nov;109(11):2699-709. http://dx.doi.org/10.1002/bit.24706

48. Tirino V, Desiderio V, Paino F, De Rosa A, Papaccio F, La Noce M, et al. Cancer stem cells in solid tumors: An overview and new approaches for their isolation and characterization. Faseb J. 2013 Jan;27(1):13-24. http://dx.doi.org/10.1096/fj.12-218222

49. Salmaggi A, Boiardi A, Gelati M, Russo A, Calatozzolo C, Ciusani E, et al. Glioblastoma-derived tumorospheres identify a population of tumor stem-like cells with angiogenic potential and enhanced multidrug resistance phenotype. Glia. 2006 Dec;54(8):850-60. http://dx.doi.org/10.1002/glia.20414

50. Lu C, Shervington A. Chemoresistance in gliomas. Mol Cell Biochem. 2008 May;312(1-2):71-80. http://dx.doi.org/10.1007/s11010-008-9722-8 
51. Bao S, Wu Q, McLendon RE, Hao Y, Shi Q, Hjelmeland AB, et al. Glioma stem cells promote radioresistance by preferential activation of the DNA damage response. Nature. 2006 Dec 07;444(7120): 756-60. http://dx.doi.org/10.1038/nature05236

52. Ishiguro T, Ohata H, Sato A, Yamawaki K, Enomoto T, Okamoto K. Tumor-derived spheroids: Relevance to cancer stem cells and clinical applications. Cancer Sci. 2017 Mar;108(3):283-9. http:// dx.doi.org/10.1111/cas.13155

53. Podberezin M, Wen J, Chang C-C. Cancer stem cells A review of potential clinical applications. Arch Pathol Lab Med. 2013 Aug;137(8):1111-16. http://dx.doi.org/10.5858/arpa.2012-0494-RA

54. Giddings JC. Field-flow fractionation: Analysis of macromolecular, colloidal, and particulate materials. Science. 1993;260(5113):1456-65. http://dx.doi.org/10.1126/science.8502990

55. Bégaud-Grimaud G, Battu S, Leger DY, Cardot PJP. Mammalian cell sorting with sedimentation field flow fractionation. In: Williams SKR, Caldwell KD, editors. Field-flow fractionation in biopolymer analysis. Wien: Springer-Verlag; 2012; 223-253.

56. Guglielmi L, Battu S, Le Bert M, Faucher JL, Cardot PJP, Denizot Y. Mouse embryonic stem cell sorting for the generation of transgenic mice by sedimentation field-flow fractionation. Anal Chem. 2004;76:1580-5. http://dx.doi.org/10.1021/ac030218e

57. Mélin C, Perraud A, Akil H, Jauberteau MO, Cardot P, Mathonnet M, et al. Cancer stem cell sorting from colorectal cancer cell lines by sedimentation field flow fractionation. Anal Chem. 2012;84(3): 1549-56. http://dx.doi.org/10.1021/ac202797z

58. Bégaud-Grimaud G, Battu S, Lazcoz P, Castresana JS, Jauberteau MO, Cardot PJP. Study of the phenotypic relationship in the IMR-32 human neuroblastoma cell line by sedimentation field flow fractionation. Int J Oncol. 2007;31:883-92. http://dx.doi.org/10.3892/ijo.31.4.883

59. Bertrand J, Begaud-Grimaud G, Bessette B, Verdier M, Battu S, Jauberteau MO. Cancer stem cells from human glioma cell line are resistant to fas-induced apoptosis. Int J Oncol. 2009;34:717-27.

60. Lautrette C, Cardot PJP, Vermot-Desroche C, Wijdenes J, Jauberteau MO, Battu S. SdFFF purification of immature neural cells from a human tumor neuroblastoma cell line. J Chromatogr B. 2003;791:149-60. http://dx.doi.org/10.1016/S1570-0232(03)00229-0

61. Pinet S, Bessette B, Vedrenne N, Lacroix A, Richard L, Jauberteau MO, et al. TrkB-containing exosomes promote the transfer of glioblastoma aggressiveness to YKL-40-inactivated glioblastoma cells. Oncotarget. 2016 Aug 02;7(31):50349-64.

62. Gourlay J, Morokoff AP, Luwor RB, Zhu HJ, Kaye AH, Stylli SS. The emergent role of exosomes in glioma. J Clin Neurosci. 2017 Jan;35:13-23. 